\title{
Firm-level estimates of capital stock and productivity
}

\section{SUMMARY}

Recent empirical work has highlighted the importance of firm-level studies in explaining productivity trends over time and across industries and countries. Using the microdata sets, made available within the Virtual Microdata Laboratory (VML) at the Office for National Studies (ONS), has made exploring the richness of differing firm characteristics and their impact on productivity possible. This article reviews the recent literature, and describes how a new firm-level capital stock series has been created. This will provide a gateway to future academic research and inform policy on productivity and firm performance.

\section{Productivity and growth accounting}

D roductivity is generally understood to be the long term driver of economic growth because an economy can only grow to a finite extent by simply using more inputs of labour and capital, which are in themselves, in limited supply. For growth to be sustained it is therefore necessary for more and more output to be created from the same physical inputs.

Growth accounting frameworks attempt to break down the growth in output into that stemming from changes in inputs and that from productivity. Typically the framework is based on a production function where output $(\mathrm{Y})$ is a function of technology or productivity (A), labour (L) and capital (K). For example, a commonly used functional form for a production function is

$Y=A K^{\alpha} L^{\beta}$

Where $\alpha$ and $\beta$ reflect the elastisticity (or sensitivity) of output to inputs of capital and labour respectively. The advantage of this specification is that it easily allows growth to be decomposed into its various parts, i.e. the growth in productivity and inputs of capital and labour.

$$
\begin{aligned}
\frac{\Delta Y}{Y} & \approx \frac{\Delta A}{A}+\alpha \frac{\Delta K}{K}+\beta \frac{\Delta L}{L} \\
& \text { or } g_{Y} \approx g_{A}+\alpha g_{K}+\beta g_{L}
\end{aligned}
$$

In the growth accounting framework productivity is essentially a residual, representing the contribution to output growth that cannot be accounted for by changes in inputs.

$g_{A}=g_{Y}-\alpha g_{K}-\beta g_{L}$

In early growth models productivity was simply viewed as exogenous. Economies grew through the accumulation of labour and capital with productivity or technological change effectively treated as manna from heaven. However, as the economic literature developed, studies increasingly looked at factors that could account for the productivity residual with the aim of guiding policy. Most of this early literature analysed growth at the economy-wide or industry level, for example by including extra variables in the production function to account for the spill-over effects from investment and spending on human capital.

However, macro studies do not allow for the richness of differing firm characteristics and their impact on productivity to be explored. Foster et al (2000) reports that within US manufacturing roughly half of the multi-factor productivity growth can be accounted for by the re-allocation of outputs and inputs away from the less productive to more productive firms. Barnes and Martin (2002) reached a similar conclusion for the UK, with the exit of old firms and the arrival of new ones seen to make an important contribution to productivity. Furthermore, aggregate measures can hide a huge amount of heterogeneity, even between the firms within very narrowly defined industries. 
Therefore, micro studies of productivity have grown in importance seeking to identify the factors that drive the most productive firms, e.g. technology use, international reach, industry and geographical effects etc. The biggest obstacle though to date has been empirical, because firm-level studies require firm-level data and estimation of firm-level production functions. Criscuolo et al (2003) set out the general approach to building the evidence base, noting how micro studies can inform business and industrial policy.

The Virtual Microdata Laboratory (VML) is a depository of firm-level data which Office for National Statistics (ONS) makes available to approved researchers and has already supported a large volume of academic and policy work ${ }^{1}$. However, ONS does not ask firms what their capital stocks are; so up until now, researchers wishing to investigate drivers of productivity growth originating from the firm-level were forced to construct their own measures of capital stock- a timely and by no means simple process. The main purpose of this paper is to outline how a firm-level measure of capital stock has been constructed. By linking these to the other confidential data sets held within the VML it is hoped to provide a gateway to future work on productivity and firm performance.

\section{The Virtual Micro-data Laboratory (VML) and firm-level studies of productivity}

The VML is a facility within ONS which enables access to restricted microdata for research purposes. It is a secure technical environment, and it adheres to strict disclosure control principles to ensure full confidentiality of all data. The Microdata Analysis \& User Support (MAUS) team ${ }^{2}$ is responsible for running the laboratory, and has recently made a new and improved version of the capital stock data set available. It spans the years 1979-2005, and creates a firm-level estimate of capital stock for approximately 42,000 enterprises. The provision of this capital stock data set, linked to other datasets in the VML, puts ONS at the frontier of driving forward academic and government research in firmlevel productivity.

One of the key advantages of microdata, rather than macro-level statistics, is that they permit the examination of a great deal of variability that occurs at firm-level. It is possible to isolate the effects of factors such as region, firm size and foreign ownership on the productivity of individual businesses. Studies using data sets within the VML have already made an important and interesting contribution to the literature and policy.

Using microdata, Oulton (1998a) presents new evidence on the growth in UK manufacturing productivity during the 1980s. Conventional thought was that increased global competition from the Asian Tiger economies, the strong pound resulting from the development of North Sea oil, and the impact of the recession at the start of the decade acted to remove the least productive firms, thus raising the average productivity level of the surviving firms. Oulton's view though was that closures did not play a role in productivity growth as those exiting were replaced by new entrants with equally low productivity. Instead, overall productivity improvements were due to growth within survivors, particularly in larger firms that downsized employment.

Microdata have also been used to explore the productivity effects of new information and communication technologies (ICT). Criscuolo and Waldron (2003), using evidence from the E-commerce Survey and other linked VML data sets, found significant productivity gains are associated with the use of electronic procurement systems within firms. Electronic networks helped to receive and place orders, cut administrative costs, speed up transactions and reduce search costs. Goodridge and Clayton (2004), also using the E-commerce Survey, went further. Their results showed that productivity was not just enhanced through buying and selling networks but by how they transformed the internal operations of an enterprise.

Similar findings were reached by Rincon et al (2005) who, looking at the firmimpact of e-commerce, found that buying and selling on-line had a positive effect on productivity for both manufacturing and services sector firms. However, for services sector firms, e-selling was more important. At the plant level, benefits were accrued from lower administrative costs and better supply-chain management.

Sadun (2005) investigated the role of hardware and software spending on firmlevel productivity, and found a significant positive effect over the sample 1995-2003. In fact the doubling of IT investment improved firm-productivity growth by $2-4$ per cent in this period. Farooqui (2005) attempts to investigate the entire impact of ICT investment on firm performance, also finding software and hardware spending had a positive effect on productivity. Employee use of IT and the internet is correlated with investment at the firm-level, but has a larger effect over and above the investment effect, particularly in servicesbased firms. Telecommunication spending also accounts for a large part of inter-firm productivity differences in manufacturing and services. And confirming earlier studies, e-commerce was also an important determinant of firm productivity.

Empirical work by Bloom et al (2005) investigated why productivity growth in sectors that used ICT appeared to accelerate faster in the US than Europe since 1995.

Taking a sample of US multinational companies in Europe, relative to domestic and other multinational companies, there was a clear US productivity leadership, but almost all of the advantage was due to the superior management and organizational structure. This prompted the conclusion that it was not so much IT that matters for productivity, but how it was used within the firm.

This study also contributes to another strand of productivity analysis work that has been carried out within the VMLusing data on multinational firms to account for international differences in productivity. It was largely thought that the US environment of less regulation, more competition, a bigger market, better access to risk capital and a more flexible labour market was responsible for its productivity advantage. However, this study refutes the notion, instead putting it down to the internal organization and management practices of US firms.

Oulton (1998b) found that value-added per worker was 38 per cent higher in the UK affiliates of foreign manufacturers than in domestic establishments. Human and physical capital intensity was an important factor in explaining productivity gaps. However, even allowing for extra capital intensity, US forms had a productivity advantage of 9-20 per cent. This could be down to superior management, or that foreign owners are particularly adept at taking-over relatively productive domestic plants.

These results have been corroborated in subsequent research. Griffith et al (2002) found that growing foreign ownership at the establishment level might help to close the productivity gap at the aggregate level. Their study finds that foreign multinationals make up a large proportion of firms at the technological frontier, contributing to growth through technology transfers. Therefore increased foreign presence in industry speeds up convergence to the technology frontier and closes the international productivity gap. Criscuolo 
and Martin (2007) conducted a study of US and other foreign-owned plants in the UK. Like Bloom et al, they conclude the US business environment is not responsible for US leadership. Nor is it the sharing of superior firm assets, but the takeover of already productive UK plants. High productivity within the UK affiliates of US multinationals stems from the ability to pick winners in mergers and acquisitions.

\section{Constructing firm-level estimates of capital stock}

The main purpose of this article is to briefly outline the various steps taken to produce the firm-level capital stock data set now available for use in the VML. These are

- using the Perpetual Inventory Model (PIM) to create estimates of capital stock from investment data

- identifying suitable data sources for use in the PIM

- describing how initial or starting values of capital stock for firms can be allocated from the aggregate capital stock

- outlining the possible imputation techniques to deal with missing values

- and addressing the problem of negative capital stock series

Capital stocks, unlike the majority of other data sets held in the VML, are a 'constructed' series. As such a number of assumptions are required and there is not a definite approach to take. Martin (2002, 2007) provides an overview of these issues. Because assumptions can affect outcomes a major development in this latest version of the capital stock data set is the ability for users to tailor the data for their own purposes by selecting from a range of key variables and methods. A more complete description of how these data are produced and the options available to researchers can be found in Gilhooly (2009).

\section{Perpetual Inventory Model}

A PIM is a simple method of producing a capital stock estimate from data on investment flows.

$K_{t}=(1-d) * K_{t-1}+I_{t}$

The capital stock in period $\mathrm{t}\left(K_{t}\right)$ is equal to the capital stock in the previous period after accounting for depreciation (where $d$ is the rate of depreciation), plus new additions to the capital stock in terms of net-investment $\left(I_{t}\right)$.

For each firm the PIM is run for three different types of capital assets which are plant and machinery, buildings and vehicles. Annual depreciation rates for each asset, as set out in ONS (2007), are 6 per cent, 2 per cent and 20 per cent respectively. It is also important to realize that netinvestment, referring to the acquisition minus disposals of capital assets, can be positive or negative in any year.

\section{Data sets}

The capital stock data set is constructed from the Annual Respondents Database Panel Data (ARDPD) set, which is a longitudinal data set based primarily on successive waves of the Annual Business Inquiry (ABI). The $\mathrm{ABI}$ is the most comprehensive business survey conducted by ONS and covers over 100 key economic variables, such as: turnover, production and operation costs, employment, industry classification, and investment. The ABI has surveyed all sectors since 1997, while firms in the manufacturing and construction sectors have returned questionnaires from 1973 and 1994 respectively. It is a census of large businesses, and a stratified sample of small and medium sized enterprises.

The stratified sampling framework means that smaller firms move in and out of the survey, but in order to run the PIM it is necessary to have a complete time series. The ARDPD solves this problem by imputing entries for firms when they do not appear in the ABI, but are still trading. For example, if a firm is included in the survey in 1997 and 2000, the ARDPD ensures there are also entries for 1998 and 1999. The way missing values are imputed is described later in the article.

Along with a complete time series, operating a PIM also requires a starting value or an initial estimate of capital stock for each firm. This is achieved by allocating a share of aggregate capital stock for the first year that they appear in the survey. The aggregate capital stock series of choice is the Volume Index of Capital Services (VICS). Capital services are a flow measure reflecting the input of capital into production, so are deemed more suitable for analysing productivity than National Accounts wealth estimates of capital stocks. More information on VICS can be found in Wallis and Dey-Chowdhury (2007).

\section{Initial capital stock estimates}

A starting value of firm capital stock is required before a PIM can be run, which is achieved by allocating a proportion of total industry capital stock to each firm for the first year it appears in the ARDPD. This requires a variable which is plausibly related to capital stock and is available for all years. The two main options are 'total purchases' and 'materials \& fuels', both of which could plausibly be correlated with capital stock and firms are asked these questions in all years. Alternatives, which are only available from 1997 onwards, include: 'number of local units', 'spending on insurance' and 'spending on road transport'. As stated previously, users can determine their own variable of choice from among these options in constructing capital stock data. Hence, a basic allocation of firm-level capital can be created using:

$\operatorname{Share}(m 0)=\left[k e y \mathrm{var} / \sum k e y\right.$ var $]$

We shall refer to this basic formula as Method $0(\mathrm{~m} 0)$. However, this is only able to split capital at the level of Standard Industrial Classification (SIC) letters. Consider sectors in the same SIC letter (a) but different SIC letter sub-divisions (e.g. $\mathrm{a} 1=$ Plumbing, $\mathrm{a} 2=$ Civil engineering).

Table 1 provides an example of how initial capital stock would be allocated to firms using $\mathrm{m} 0$ and total purchases.

An extra variable can be used to refine the allocation. For example, in Method 1 (m1) total purchases can be used to determine the shares within a sub-division, and employment to determine the shares between sub-divisions.

$$
\begin{aligned}
& \text { Share }(m 1)= \\
& {\left[\text { totpurch }^{\prime} / \sum \text { totpurch }_{\text {sub-div }}\right] *} \\
& {\left[\sum \text { employment }_{\text {sub-div }} / \sum\right. \text { employment }}
\end{aligned}
$$

An example of $\mathrm{m} 1$ using the same data in Table 1 is presented in Table 2 . A further approach, Method $2(\mathrm{~m} 2)$, simply reverses the order in $\mathrm{m} 1$. Here employment is used to determine capital stock allocation within a SIC sub-division, and total purchases between them. The flexible set-up of the capital stock data set ultimately allows the user to define these choices of key variables and methods.

Initial allocations of capital stock are both tricky and crucial. If a firm's initial allocation of stock is too low it is possible for a capital stock to become negative when the PIM is run which is implausible. This is highly likely for stocks of vehicles, as it is not uncommon for disposals to exceed acquisitions for a given period of time. Investigative work, as reported in Table 3, 
Table 1

An example of allocating initial capital stocks using Method $0(\mathrm{~m} 0)$

\begin{tabular}{llllll}
\hline Method & Firm & SIC letter & SIC code & Total purchases & Share of capital \\
\hline $\mathrm{m0}$ & 1 & $\mathrm{a}$ & $\mathrm{a} 1$ & 20 & $(20 / 190)=0.11$ \\
$\mathrm{~m} 0$ & 2 & $\mathrm{a}$ & $\mathrm{a} 1$ & 20 & $(20 / 190)=0.11$ \\
$\mathrm{~m} 0$ & 3 & $\mathrm{a}$ & $\mathrm{a}$ & 50 & $(50 / 190)=0.26$ \\
$\mathrm{~m} 0$ & 4 & $\mathrm{a}$ & $\mathrm{a}$ & 100 & $(100 / 190)=0.53$ \\
\hline
\end{tabular}

Table 2

An example of allocating initial capital stocks using Method 1 (m1)

\begin{tabular}{|c|c|c|c|c|c|c|c|c|}
\hline Method & Firm & $\begin{array}{l}\text { SIC } \\
\text { letter }\end{array}$ & $\begin{array}{l}\text { SIC } \\
\text { code }\end{array}$ & $\begin{array}{l}\text { Total } \\
\text { purchases }\end{array}$ & $\begin{array}{l}\text { Share } \\
\text { within sub- } \\
\text { divisions }\end{array}$ & Employment & $\begin{array}{l}\text { Share } \\
\text { across sub- } \\
\text { divisions }\end{array}$ & Share of capital \\
\hline $\mathrm{m} 1$ & 1 & $a$ & a1 & 20 & $(20 / 40)=0.5$ & 50 & $(75 / 770)=0.1$ & $\left(0.5^{*} 0.1\right)=0.05$ \\
\hline $\mathrm{m} 1$ & 2 & a & a1 & 20 & $(20 / 40)=0.5$ & 25 & $(75 / 770)=0.1$ & $\left(0.5^{*} 0.1\right)=0.05$ \\
\hline $\mathrm{m} 1$ & 3 & $\mathrm{a}$ & a2 & 50 & $(50 / 150)=0.33$ & 200 & $(700 / 770)=0.9$ & $\left(0.33^{*} 0.9\right)=0.30$ \\
\hline $\mathrm{m} 1$ & 4 & a & a2 & 100 & $(100 / 150)=0.67$ & 500 & $(700 / 770)=0.9$ & $\left(0.67^{*} 0.9\right)=0.60$ \\
\hline
\end{tabular}

Table 3

\section{Counts of the number of negative capital stock series created under different methods and key variables}

\begin{tabular}{lrrrr}
\hline $\begin{array}{l}\text { Method and key } \\
\text { variable }\end{array}$ & All assets & $\begin{array}{r}\text { Plant and } \\
\text { machinery }\end{array}$ & Vehicles & Buildings \\
\hline m0 Total purchases & 229 & 173 & 1,719 & 207 \\
m0 Materials and fuel & 622 & 444 & 4,888 & 943 \\
m1 Total purchases & 216 & 164 & 1,652 & 189 \\
m1 Materials and fuel & 613 & 446 & 4,719 & 853 \\
m2 Total purchases & 293 & 220 & 2,596 & 333 \\
m2 Materials and fuel & 393 & 282 & 4,525 & 689 \\
\hline
\end{tabular}

Table 4

Interpolating firm-level employment time series

\begin{tabular}{lrr}
\hline Year & $\begin{array}{r}\text { Original cells } \\
\text { Employment }\end{array}$ & $\begin{array}{r}\text { Final cells } \\
\text { Adjusted Employment }\end{array}$ \\
\hline 1980 & 0 & 108 \\
1981 & 0 & 111 \\
1982 & 0 & 113 \\
1983 & 100 & 100 \\
1984 & 120 & 120 \\
1985 & 120 & 120 \\
1986 & 114 & 114 \\
1987 & - & 132 \\
1988 & 150 & 150 \\
1989 & 170 & 170 \\
1990 & 165 & 165
\end{tabular}

Table 5

Using the capital expenditure to employment ratio to impute missing values

\begin{tabular}{lrrr}
\hline Year & $\begin{array}{r}\text { Capital } \\
\text { expenditure }\end{array}$ & $\begin{array}{r}\text { Employment } \\
\text { Imputed capital } \\
\text { expenditure }^{1}\end{array}$ \\
\hline 1985 & - & 100 & 1,282 \\
1986 & - & 145 & 1,859 \\
1987 & 20000 & 200 & 20,000 \\
1988 & 13000 & 190 & 13,000 \\
1989 & - & 250 & 3,205 \\
1990 & -17000 & 200 & $-17,000$ \\
1991 & -6000 & 190 & $-6,000$ \\
1992 & - & 230 & 2,949 \\
\hline
\end{tabular}

Notes:

1 Average capital expenditure in 1987, 1988, 1990 and $1991=2,500$

Average employment in 1987, 1988, 1990 and $1991=195$

Average capital expenditure per employee $=2500 / 195=12.82$ shows that using Method 1 and total purchases as the key variable produces the best results in terms of fewest negative capital series.

Techniques to impute missing values A complete time series is critical for the compilation of firm-level capital stocks so missing values in the panel data set need to be imputed. Employment is used as the spine for many of the imputations, and also in the allocation of the aggregate capital share, thus the first stage is to ensure that there is a complete employment series. Generally this information is available from the Inter-Departmental Business Register (IDBR) hence, even if a firm does not respond to the questions in the ABI survey, an employment figure will most likely be available. When a cell value is missing between years we simply interpolate the value. Missing cell values (usually coded 0 ) are more common in the first years of a company's existence, and these are filled in rolling back a threeyear average of the employment figures available. These techniques are illustrated in Table 4.

The investment series in the ARDPD are net capital expenditure by asset, i.e. they record the acquisitions minus disposals of each asset. Only a net-investment figure is required for the PIM, but given the volatility in firm-level investment series imputation can be challenging.

Again there isn't a definite approach, but it was decided that using the firmlevel employment series is preferable as at least the imputation is based on some real information, and because employment series are fairly complete. The simple procedure is to calculate the average net capital expenditure per employee for the available observations, and then use this figure to impute missing investment data from the employment series. An example is shown in Table 5.

While it is possible to impute for any number of missing values the quality of the imputation will suffer when we have fewer real observations on which to base calculations. For example, it could be possible to impute disposals of capital for all years for some firms. Currently the ratio of imputed to real values is set at a maximum of 1:1 in the capital stock dataset which produces a total of nearly 42,000 firm capital stock series. Lowering the intolerance to imputed values will create estimates of firm capital stock for many more firms, and is likely to pickup more small and medium enterprises 
Table 6

\section{Number of firms with estimated capital stock series at different tolerance levels}

\begin{tabular}{ll}
\hline $\begin{array}{l}\text { Tolerance level (ratio of imputed } \\
\text { to real observations) }\end{array}$ & $\begin{array}{l}\text { Number of firms with } \\
\text { capital stock series }\end{array}$ \\
\hline $1: 3$ & 13,131 \\
$2: 3$ & 21,809 \\
$1: 1$ & 41,782 \\
$3: 2$ & 50,622 \\
$2: 1$ & 74,356 \\
\hline
\end{tabular}

Table 7

\section{Number of firms with estimated capital stock series at different} tolerance levels

\begin{tabular}{lllll}
\hline SIC code & Industry description & Tolerance level & $\alpha$ & $\beta$ \\
\hline 11 & Crude Extraction & $1: 3$ & 0.790 & 0.271 \\
11 & Crude Extraction & $2: 3$ & 0.587 & 0.335 \\
11 & Crude Extraction & $1: 1$ & 0.593 & 0.355 \\
11 & Crude Extraction & $3: 2$ & 0.596 & 0.377 \\
11 & Crude Extraction & $2: 1$ & 0.597 & 0.384 \\
52 & Retail & $1: 3$ & 0.430 & 0.588 \\
52 & Retail & $2: 3$ & 0.390 & 0.618 \\
52 & Retail & $1: 1$ & 0.328 & 0.703 \\
52 & Retail & $3: 2$ & 0.306 & 0.723 \\
52 & Retail & 0.289 & 0.743 \\
72 & Computer \& related & $1: 3$ & 0.253 & 0.761 \\
72 & Computer \& related & $2: 3$ & 0.161 & 0.881 \\
72 & Computer \& related & $1: 1$ & 0.187 & 0.831 \\
72 & Computer \& related & $3: 2$ & 0.211 & 0.797 \\
72 & Computer \& related & $2: 1$ & 0.220 & 0.786 \\
\hline
\end{tabular}

due to the stratified sampling framework within the ABI. Table 6 outlines the number of firms for which we calculate capital stock given different tolerance levels.

As Table 6 shows, the number of firms for which a capital stock series can be created increases as a higher ratio of imputed to real observations is allowed. In Table 7, the production function coefficients are shown for a small variety of different industries as the tolerance to imputed values increases.

The selection of industries in Table 7 reflects differing capital intensities of production. Crude oil and gas extraction is a strongly capital intensive industry, hence the coefficient on capital inputs $(\alpha)$ is relatively high. Computer and related activities though is more labour intensive, hence the coefficient on labour inputs in the production function $(\beta)$ is relatively higher.

Altering the tolerance to the use of imputed values has a noticeable effect on the estimated coefficients. Given the stratified sampling of small and medium sized enterprises, it is not surprising that as the tolerance level increases the coefficient on capital in the production function falls; because capital stocks are generated for more smaller, less capital intensive, firms. This is not so much the case with the computer and related activities industry, as here the capital intensity of larger and smaller firms is less likely to differ than in the crude oil extraction and retailing industries. The results suggest that for this industry the mix between labour and capital inputs is similar across different firm sizes.

Dealing with the remaining negative capital stock series

It is perfectly possible that after running a PIM a firm may end up with negative capital stock in some years. This could result from a too low allocation of initial capital stock, an inaccurate imputation of net-investment or a mixture of both. In reality it is impossible for a firm to hold negative stocks of physical capital as plant and machinery, vehicles and buildings are all tangible assets.

To correct this, additional capital stock is injected at the firm level reflecting that previous estimates of capital stock and/ or investment were too small. This can be done by stipulating that a firm's capital stock must not go below zero, increasing the investment figures in the proceeding years and then re-running the PIM.

\section{Notes}

1 Detailed information about the data sets held in the VML can be found at: www.ons.gov.uk/about/who-we-are/ our-services/vml/about-the-vml/ datasets-available/dataset-downloads/ index.html

2 Maus@ons.gsi.gov.uk

\section{CONTACT}

지리ons.gsi.gov.uk

\section{REFERENCES}

Barnes M and Martin R (2002) 'Business data linking: an introduction', Economic Trends No. 581, pp 34-41 and at: www.statistics.gov.uk/cci/article.asp? ID =135 Bloom N, Van Reenen J and Sadun R, (2005) 'It Ain't What You Do, it's the way that you do IT', Centre for Economic Performance, London School of Economics.

Criscuolo C, Haskel J and Martin R (2003) 'Building the evidence base for productivity policy using business data linking', Economic Trends No. 600, pp 39-51 and at: www.statistics.gov.uk/cci/article.asp? ID =598

Criscuolo C and Martin R (2007)

'Multinationals and US productivity leadership, evidence from Great Britain', Centre for Research in Business Activity (CeRiBA)

Criscuolo C and Waldron K (2003)

'E-commerce and productivity', Economic Trends No. 600, pp 52-57 and at: www.statistics.gov.uk/cci/article. asp? ID =597

Farooqui S (2005) 'Information and communication technology use and productivity', Economic Trends 625, pp 65-74 and at:

www.statistics.gov.uk/cci/article.asp? ID =135

Foster L, Haltiwanger J and Krizan C J (1998)

'Aggregate productivity growth: lessons from microeconomic evidence', Center for Economic Studies, U.S. Census Bureau, Working Paper 98-12

Gilhooly R. (2009) 'Estimating capital stock at the firm level', VML Data Brief, Winter 2008 and at:

www.ons.gov.uk/about/who-we-are/ourservices/vml/about-the-vml/outputs-andpublications/index.html

Goodridge P and Clayton T (2004) 'E-business and labour productivity in manufacturing and services', Economic Trends No. 609, pp 47-53 and at:

www.statistics.gov.uk/cci/article. asp? ID $=9455$ 
Griffith R, Redding S and Simpson H (2002) 'Productivity convergence and foreign ownership at the establishment level', Institute for Fiscal Studies (IFS) Working Paper $02 / 22$

Martin, R (2002) 'Building the capital stock'", Centre for Research in Business Activity (CeRiBA)

Martin R (2007) 'TFP without capital stocks', Centre for Research in Business Activity (CeRiBA)

ONS (2007) 'The ONS productivity handbook: a statistical overview and guide', available at: www.statistics.gov.uk/StatBase/Product.asp? $v \mid n k=14900 \&$ Pos $=3 \&$ ColRank $=1 \&$ Rank $=208$
Oulton N (1998a) 'A tale of two cycles: closure, downsizing and productivity growth in UK manufacturing, 1973-89', National Institute of Economic and Social Research Discussion Paper No. 140

Oulton N (1998b) 'Investment, capital and foreign ownership in UK manufacturing', National Institute of Economic and Social Research Discussion Paper No.141

Rincon A, Robinson, C and Vecchi M (2005) 'The productivity impact of e-commerce in the UK, 2001: evidence from microdata' National Institute of Economic and Social Research (NIESR) Discussion Paper No. 257
Sadun R (2005) 'The role of IT in firm productivity; evidence from UK micro data', Economic Trends No. 625, pp 55-64 and at: www.statistics.gov.uk/cci/article. asp? ID $=1234$

Wallis G and Dey-Chowdhury S (2007) 'Volume of capital services: estimates for 1950 to 2006 '. Economic \& Labour Market Review, Vol 1, No.12 and at: www.statistics.gov.uk/cci/article. asp? ID $=1905$ 